\title{
The impact of short-term exposure to near shore stressors on the early life stages of the reef building coral Montipora capitata
}

\author{
Claire VA Lager ${ }^{\text {Corresp., } 1,2}$, Mary Hagedorn ${ }^{1,2}$, Ku' $^{\prime}$ ulei S Rodgers ${ }^{2}$, Paul L Jokiel ${ }^{2}$ \\ ${ }^{1}$ Department of Reproductive Sciences, Smithsonian Conservation Biology Institute, Front Royal, Virginia, United States \\ 2 University of Hawai'i, Hawai'i Institute of Marine Biology, Kāne'ohe, Hawai'i, United States of America \\ Corresponding Author: Claire VA Lager \\ Email address: lagerc@hawaii.edu
}

Successful reproduction and survival are crucial to the continuation and resilience of corals globally. As reef waters warm due to climate change, episodic largescale tropical storms are becoming more frequent, drastically altering the near shore water quality for short periods of time. Therefore, it is critical that we understand the effects warming waters, fresh water input, and run-off have on sexual reproduction of coral. To better understand the effects of these near shore stressors on Hawaiian coral, laboratory experiments were conducted at the Hawai'i Institute of Marine Biology to determine the independent effects

of suspended sediment concentrations (100 $\mathrm{mg} \mathrm{l}^{-1}$ and $200 \mathrm{mg} \mathrm{l}^{-1}$ ), lowered salinity (28\%o), and elevated temperature $\left(31^{\circ} \mathrm{C}\right)$ on the successful fertilization, larval survival, and settlement of the scleractinian coral Montipora capitata. In the present study, early developmental stages of coral were exposed to one of three near shore stressors for a period of $24 \mathrm{~h}$ and the immediate (fertilization) and latent effects (larval survival and settlement) were observed and measured. Fertilization success and settlement were not affected by any of the treatments; however, larval survival was negatively affected by all of the treatments by $50 \%$ or greater $(p>0.05)$. These data shows that early life stages of M. capitata may be impacted by near shore stressors associated with warming and more frequent storm events. 
1 The impact of short-term exposure to near shore stressors on the early life stages of the reef

2 building coral Montipora capitata

3

4 Claire V.A. Lager ${ }^{1,2^{*}}$, Mary Hagedorn ${ }^{1,2}$, Ku $^{\text {'ulei S. Rodgers }}{ }^{1}$, Paul L. Jokiel ${ }^{1}$

5

6 1 University of Hawai 'i, Hawai'i Institute of Marine Biology, Kāne ‘ohe, Hawai'i, United States

7 of America

$8 \quad{ }^{2}$ Department of Reproductive Sciences, Smithsonian Conservation Biology Institute, Front

9 Royal, Virginia, United States

10

11 Corresponding author:

12 Claire V.A. Lager

13 Email address: lagerc@si.edu

14

15

16 Keywords: coral reproduction, sediment, salinity, temperature

17

18

19

20

21

22

23 


\section{Abstract}

Successful reproduction and survival are crucial to the continuation and resilience of

27 corals globally. As reef waters warm due to climate change, episodic largescale tropical storms are becoming more frequent, drastically altering the near shore water quality for short periods of time. Therefore, it is critical that we understand the effects warming waters, fresh water input, and run-off have on sexual reproduction of coral. To better understand the effects of these near shore stressors on Hawaiian coral, laboratory experiments were conducted at the Hawai' $i$ Institute of Marine Biology to determine the independent effects of suspended sediment concentrations (100 $\mathrm{mg} \mathrm{l}^{-1}$ and $\left.200 \mathrm{mg} \mathrm{l}^{-1}\right)$, lowered salinity (28\%o), and elevated temperature $\left(31^{\circ} \mathrm{C}\right)$ on the successful fertilization, larval survival, and settlement of the scleractinian coral Montipora capitata. In the present study, early developmental stages of coral were exposed to one of three near shore stressors for a period of $24 \mathrm{~h}$ and the immediate (fertilization) and latent effects (larval survival and settlement) were observed and measured. Fertilization success and settlement were not affected by any of the treatments; however, larval survival was negatively affected by all of the treatments by $50 \%$ or greater $(\mathrm{p}>0.05)$. These data shows that early life stages of $M$. capitata may be impacted by near shore stressors associated with warming and more frequent storm events.

\section{Introduction}

4 Coral reefs are among the most productive and diverse ecosystems in the world and these vulnerable ecosystems are rapidly experiencing global decline (Bellwood 2004; Wilkinson 2000). They provide indispensable ecological services such as shoreline protection, food 
47 production, and are highly attractive to tourism (Oliver 2011). There are many stressors

48 impacting the condition of coral reefs, both globally and locally. Global impacts include issues

49 related to climate change such as sea surface temperature rise and ocean acidification

50 (McClanahan et al. 2007; Spalding \& Brown 2015). Local impacts include fishing pressure,

51 nutrification, coastal construction, dredging, increased sedimentation, invasive species, and

52 freshwater runoff. All of the aforementioned stressors have been shown to negatively affect the

53 condition of coral reefs (Banner 1968; Fabricius 2005; Hughes et al. 2007; Ogden \& Lobel 1978;

54 Richmond 1993; Rogers 1990).

55 Kāne'ohe Bay, $\left(21^{\circ} 28^{\prime} \mathrm{N} ; 157^{\circ} 48^{\prime} \mathrm{W}\right)$ - the largest embayment in the Hawaiian islands

56 located on the windward side of $\mathrm{O}^{`} \mathrm{ahu}$ - has been experiencing sedimentation and freshwater

57 runoff for decades (Bahr et al. 2015a). Freshwater runoff occurs during storm flooding and is a

58 common event on tropical islands that can temporarily decrease salinity (Banner 1968; Jokiel et

59 al. 1993). Such events have been shown to cause mass mortality of adult coral (Bahr et al. 2015b;

60 Banner 1968; Jokiel et al. 1993) and could pose a threat to the early life history of coral

61 (Babcock et al. 1986; Kolinski \& Cox 2003). In the past 100 years, the corals of Kāne'ohe Bay

62 have been chronically impacted by sediment, mainly through dredging and watershed runoff

63 (Bahr et al. 2015a).

64 More recently, Kāne'ohe Bay has been experiencing warmer summer temperatures $\left(2-4^{\circ}\right.$

$65 \mathrm{C}$ above the summer average of $27^{\circ} \mathrm{C}$ ) that have resulted in coral bleaching. In 2014 and 2015,

66 Kāne'ohe Bay experienced consecutive warming events that resulted in widespread bleaching of

67 coral. With increased intensity and frequency of bleaching events coral are less likely to recover.

68 Bahr et al. (2017) surveyed coral before and after both the 2014 and 2015 bleaching events. They 
69 found that overall coral mortality was higher after the 2015 bleaching event $(5.5 \%$ in 2014 and

$70 \quad 16.0 \%$ in 2015) which suggests that consecutive bleaching events affect coral resilience.

71 The effects of local near shore stressors such as sedimentation, freshwater runoff, and

72 elevated temperatures on adult coral have been thoroughly studied (Erftemeijer et al. 2012;

73 Fabricius 2005; Humphrey et al. 2008; Jokiel et al. 2014; Rogers 1990; Te 2001). More recently,

74 studies have looked at the effects of near shore stressors on the early life stages of coral as well

75 (Edmunds et al. 2001; Hedouin et al. 2015; Humanes et al. 2017; Jones et al. 2015; Ricardo et al.

76 2015; Ricardo et al. 2018; Ricardo et al. 2017). However, very little is known about how these

77 near shore stressors affect the early life stages in Hawaiian coral. These near shore stressors were

78 selected for this study because all three have been shown to negatively affect adult coral

79 worldwide (Douglas 2003; Fabricius 2005; Rogers 1990) and in Hawai‘i (Bahr et al. 2015b;

80 Jokiel \& Brown 2004; Jokiel et al. 1993; Jokiel et al. 2014).

81 In this study we exposed gametes of the scleractinian coral $M$. capitata to three different

82 near shore stressors for $24 \mathrm{~h}$ : high sediment concentrations (100 $\mathrm{mg} \mathrm{l}^{-1}$ and $\left.200 \mathrm{mg} \mathrm{l}^{-1}\right)$, lowered

83 salinity $\left(28 \%\right.$ ), and elevated temperature $\left(31^{\circ} \mathrm{C}\right)($ Fig.1). Exposure to stressors was independent

84 and none were combined. Criteria selection for stressor levels include: 1) accurate representation

85 of Kāne'ohe Bay conditions (Table 1), and 2) comparability with historical studies conducted

86 with other Pacific species.

87 The purpose of this study was to determine whether the different stressors have

88 deleterious effects on the early life stages of $M$. capitata: 1) fertilization, 2) larval survival, and

89 3) settlement. Successful development of early life stages of coral are very important for reef

90 resilience and recovery. Therefore, understanding how these common stressors affect the early

91 life stages is imperative. 


\section{Methods and Materials}

\section{Location and study species}

95 These experiments were conducted at the Hawai' $i$ Institute of Marine Biology (HIMB) in

96 Kāne'ohe Bay $\left(21^{\circ} 28^{\prime} \mathrm{N} ; 157^{\circ} 48^{\prime} \mathrm{W}\right)$ on the windward side of $\mathrm{O}^{`}$ ahu, under the Hawai' $\mathrm{i}$

97 Department of Land and Natural Resources Special Activity Permit No. SAP 2015-48. M.

98 capitata is the second most common coral species in Kāne 'ohe Bay and the third most common

99 throughout the Hawaiian Islands (Jokiel et al. 2004; Rodgers 2005). M. capitata is a

100 hermaphroditic broadcast-spawner, releasing positively buoyant egg and sperm bundles during

101 the months of May through August between the hours of 22:45 and 22:30 on and , 2-3 days

102 following the new moon (Kolinski \& Cox 2003). Thirty-four adult coral were collected from

103 multiple patch reefs throughout Kāne'ohe Bay on 14 May and 12 June, 2015 and transported

104 back to tanks at HIMB. Coral were held in seawater tables continuously supplied with $27^{\circ} \mathrm{C}$

105 seawater pumped from the adjacent reef at $2 \mathrm{~m}$ depth. Approximately one hour prior to

106 spawning, coral colonies were isolated into individual containers. The exposure experiment was

107 replicated on three spawning nights during July 2015 with a total starting sample size of

108 approximately 33 for each treatment (Table 2). Vials with less than 10 eggs were not included

109 for analysis due to the high likelihood that only one egg-sperm bundle was added.

\section{Sediment treatment}

112 Three concentrations of sediment were used: $0 \mathrm{mg} \mathrm{l}^{-1}, 100 \mathrm{mg} \mathrm{l}^{-1}$, and $200 \mathrm{mg} \mathrm{l}^{-1}$. These

113 concentrations were chosen to mimic suspended sediment concentrations during/after a

114 largescale rain event (Table 1). Terrigenous red clay was collected from a historically 
115 undisturbed hillside at the highest elevation on Moku o Lo'e Island at HIMB. Sediment was

116 sorted using a standard sieve to $<63 \mu \mathrm{m}$. This sediment size was chosen to mimic natural

117 suspended sediment grain size. This clay/silt fraction was added to a $1 \mathrm{~L}$ beaker of seawater,

118 allowed to settle and the clear supernatant decanted to concentrate into a sediment slurry that

119 could be more accurately measured into 100 and $200 \mathrm{mg}^{-1}$. The remaining sediment slurry was

120 used to make sediment solutions. Sediments were not allowed to desiccate completely, which

121 can alter the chemical composition and also impede re-suspension (Jokiel 1986). A wet weight to

122 dry weight ratio was determined in order to obtain an accurate suspended sediment

123 concentration. The wet slurry was weighed and dried several times to obtain an accurate wet to

124 dry weight ratio. The day of the experiment, the sediment slurry was weighed to the nearest

125 milligram on a Mettler Toledo XS403S scale (Columbus, OH) in a plastic weigh pan and added

126 to $1 \mathrm{~L}$ of filtered seawater (FSW). This was repeated for each sediment concentration. All FSW

127 was filtered through a Millipore Type GS $0.22 \mu \mathrm{m}$ filter.

128

129 Salinity treatment

130 Fertilization, larval survival, and settlement of M. capitata was assessed at ambient (34

$131 \%$ ) and low (28\%) salinity. Treatment seawater was obtained from the seawater system at

132 HIMB and salinity was measured prior to use. Salinity was measured in parts per thousand (\%)

133 using a YSI Model 556 conductivity meter (Yellow Springs, OH). The $28 \%$ treatment was

134 prepared using filtered Kāne'ohe Bay seawater diluted with filtered freshwater to obtain the

135 desired salinity. The salinity of $28 \%$ was selected based on previous studies which is

136 representative of salinities measured on nearshore reefs during flood events (Hedouin et al. 2015;

137 Humphrey et al. 2008). 
139

140

141

142

143

144

145

146

147

148

149

150

151

152

153

154

155

156

157

158

159

160

\section{Temperature treatment}

Two temperature treatments were used in these experiments, ambient $\left(27^{\circ} \mathrm{C}\right.$ during the summer months), and an elevated temperature of $31^{\circ} \mathrm{C}$. The elevated temperature represents $2^{\circ}$ $\mathrm{C}$ above the summer thermal maximum, a temperature that elicits the stress response of bleaching in adult coral over a short time period (Jokiel 1977). The elevated temperature of $31^{\circ}$ C was chosen because during the 2014 bleaching event in Kāne'ohe Bay the maximum mid-day temperature was between 30 and $31^{\circ} \mathrm{C}$ (Bahr et al. 2015b).

All ambient, sediment, and salinity vials containing gametes were secured in floating foam racks and were placed in water tables to maintain temperature $\left(27^{\circ} \mathrm{C}\right)$ and simulate mild wave motion similar to field conditions. The elevated temperature treatment $\left(31^{\circ} \mathrm{C}\right)$ vials were placed in a heated water bath and were also secured in floating foam racks. Temperature was controlled with an aquarium heater and an Onset HOBO Pendant ${ }^{\circledR}$ measured the temperature over the time of exposure. Loggers have an accuracy of $\pm 0.21^{\circ} \mathrm{C}$ from 0 to $50{ }^{\circ} \mathrm{C}\left( \pm 0.38^{\circ} \mathrm{F}\right.$ from $32^{\circ}$ to $122^{\circ} \mathrm{F}$ ). Additional laboratory calibrations were conducted at 0 and $35^{\circ} \mathrm{C}$ to assure precision and account for any drift in calibrations. Mild agitation was achieved using aquarium power heads that gently circulated water in the bath.

\section{Fertilization}

Coral were placed into individual $11 \mathrm{~L}$ containers prior to spawning and water was allowed to flow in and around the containers to maintain constant water temperature. Unlike other fertilization experiments (Gilmour 1999; Hedouin et al. 2015), egg bundles were not pooled since $M$. capitata eggs contain a toxin that will effectively kill sperm within minutes if 
161 their membrane is even slightly damaged (Hagedorn et al. 2015). Pooling eggs requires more

162 handling and increases the chance of damaging membranes and releasing the toxin. Therefore,

163 fertilization was accomplished by egg-sperm bundle-bundle crosses from two individuals in 15

164 ml scintillation vials (Maté et al. 1997). A "bundle-bundle cross" consisted of one egg-sperm

165 bundle from each of two parent colonies that were loaded into a scintillation vial with $4.9 \mathrm{ml}$ of

166 filtered seawater (FSW). The final volume in each scintillation vial was $5 \mathrm{ml}$ after the bundles

167 were added. To determine the level of self-fertilization, two egg-sperm bundles from the same

168 individual were placed in a vial - no colonies used in this experiment self-fertilized. The average

169 sperm concentration of an M. capitata egg-sperm bundle is approximately $5 \times 10^{5}$ cells $/ \mathrm{ml}$

170 (Hagedorn et al. 2016). The bundle-bundle cross method has been shown to produce the optimal

171 sperm concentration $\left(\sim 1 \times 10^{6}\right.$ cells $\left./ \mathrm{ml}\right)$ for fertilization in M. capitata (Maté et al. 1997). Over

172 the three nights of spawning, 33 unique crosses were obtained. Each cross was exposed for $24 \mathrm{~h}$

173 to different treatments: 1) ambient conditions; 2) medium suspended sediment; 3) high

174 suspended sediment; 4) low salinity; and 5) high temperature (Table 3), and 6) self fertilization

175 control ( 2 bundles from same colony). Each treatment was separate and exposed to each cross in

176 a scintillation vial for $24 \mathrm{~h}$ (Fig. 1).

177 Bundles separated approximately 20 minutes after spawning and the number of eggs per vial

178 was recorded using a Wild M5 dissecting microscope at 100x magnification. The fertilization

179 count was recorded the following morning, approximately eight hours after spawning.

180

181 Larval survival

182 Twenty-four hours after spawning with continued exposure to the treatments, the

183 embryos were moved to clean vials with $5 \mathrm{ml}$ of FSW in each vial. The number of swimming 
184 larvae was determined 48 hours following spawning. The percent larval survival was calculated

185 by dividing the number of swimming larvae by the number of fertilized eggs.

186

187

Settlement

188

After counting the number of swimming larvae in each scintillation vial, larvae were

moved into $10 \mathrm{ml}$ petri dishes. A $1 \mathrm{~cm}^{2}$ chip of crustose coralline algae (CCA) and

190

approximately $10 \mathrm{ml}$ of FSW were added to each dish and were covered loosely with a lid. Every

191

two days fresh FSW was added to petri dishes and each dish and CCA chip were checked for

192

settlement during water changes. Fourteen days after spawning, settlement was determined by

193

counting the number of settled larvae. Negri et al. (2001) define settlement as a planula that is

194

still pear-shaped but has attached its aboral end to a hard substrate, whereas metamorphosis

195

involves a morphological and physiological change (i.e., flattened and with septal mesentery

196

radiating from mouth). Larvae were considered "settled" if they had metamorphosed. The

197

percent settlement was calculated by dividing the number of metamorphosed coral by the

198

number of swimming larvae.

199

200

Statistical Analyses

201

All count data for fertilization, larval survival, and settlement were counted and

202

represented as percentages. These values were transformed using an arcsine square root

203

transformation as recommended for proportional data. Data are graphically displayed as percent

204 in figures to better visualize the proportions and all error bars are Standard Error of the Mean

205 (SEM). Each treatment was individually compared to the control using a One-way ANOVA with 
206 Dunnett's Method using the statistical software program JMP Pro 12. P-values $\leq 0.05$ were 207 considered statistically significant.

208

209 Results

210

\section{Fertilization}

None of the treatments were statistically higher or lower than control fertilization success

212 of $M$. capitata (ANOVA, $\mathrm{p}>0.05$ ). The mean fertilization success for ambient conditions was 213 approximately $66.8 \pm 5.7 \%$. All suspended sediment treatments showed slightly higher mean 214 fertilization success; $77.8 \pm 4.05 \%$ in the $200 \mathrm{mg}^{-1}$ treatment and $68.7 \pm 6.3 \%$ fertilization in the $215100 \mathrm{mg} \mathrm{l}^{-1}$ treatment (Fig. 2). The low salinity treatment $(28 \%$, n $=31)$ decreased mean 216 fertilization success to $52.2 \pm 5.9 \%$, but was not statistically different from the ambient salinity 217 of $34 \%$ at $66.8 \pm 5.9 \%$. The elevated temperature treatment $\left(31^{\circ} \mathrm{C}, \mathrm{n}=29\right)$ also produced a 218 lower mean fertilization to $50.0 \pm 6.6 \%$, but was not different than the control.

\section{Larval survival}

Although fertilization appeared to be resilient to the treatments, larval survival (\% of

222 swimming larvae from fertilized eggs) decreased drastically in all of the treatments, especially

223 hypo-osmotic conditions (Fig. 2). Control larvae under ambient conditions had the highest

224 survival, $67.3 \pm 10.7 \%$ (Fig. 2) and were statistically different than all of the treatments

225 (ANOVA, $\mathrm{p}<0.05$ ). Embryos at the round, non-motile stage were removed from the treatments

226 and placed into clean seawater for the rest of the experiment; differences in larval survival were

227 due to latent effects of the treatments. 
229 control $(\mathrm{p}<0.05, \mathrm{~F}=13.9)$. The $200 \mathrm{mg} \mathrm{l}^{-1}$ sediment treatment had higher larval survival than the

$230100 \mathrm{mg} \mathrm{l}^{-1}$ treatment $(24.47 \pm 5.5 \%, 11.6 \pm 5.2 \%)$. Elevated temperature produced the highest

231 mean larval survival of all treatments, $36.4 \pm 8.6 \%$. Salinity had the most dramatic effect on

232 larval survival. The low salinity treatment had the lowest percent larval survival of all the

233 treatments, $1.14 \pm 6.1 \%($ ANOVA, $\mathrm{p}<0.05, \mathrm{~F}=38.8)$.

\section{Settlement}

236

There was no difference in percent settlement when treatments were compared with the control, $21.1 \pm 3.8 \%$ (Fig. 2). However, the means were up to $50 \%$ different in the respective 238 treatments. The $100 \mathrm{mg} \mathrm{l}^{-1}$ sediment treatment had a greater mean percent settlement than the 239 control $(39.5 \pm 14.3 \%)$, and the $200 \mathrm{mg} \mathrm{l}^{-1}$ sediment treatment had a lower mean settlement $(20.0$ $240 \pm 6.1 \%$ ) (Fig. 2). There was no settlement in the salinity treatment and, due to low survival, no

241 statistical analysis was conducted. The high temperature treatment had a lower mean percent 242 settlement than the control $(25.3 \pm 8.3 \%)$ (Fig. 2).

\section{Discussion}

The purpose of the present study was to identify the direct and latent effects of a 24-hour exposure to suspended sediment (100 $\mathrm{mg} \mathrm{l}^{-1}$ and $\left.200 \mathrm{mg} \mathrm{l}^{-1}\right)$, lowered salinity (28\%o), and

247 elevated temperature $\left(31^{\circ} \mathrm{C}\right)$ on the early life stages of the Hawaiian scleractinian coral $M$.

248 capitata. Results of this experiment show that fertilization and settlement were not affected by

249 any of the stressors, and larval survival was negatively affected by all of the near shore stressors 250 (suspended sediment, lowered salinity, and elevated temperature). 


\section{Effects of increased sediment on early life stages}

253 Neither suspended sediment treatment (100 and $\left.200 \mathrm{mg} \mathrm{l}^{-1}\right)$ had an effect on fertilization

254 but both decreased larval survival (Fig. 2). Previous and concurrent studies from the Great

255 Barrier Reef found that sediment decreased both fertilization and larval survival (Gilmour 1999;

256 Humphrey et al. 2008). Gilmour (1999) found that suspended sediment as low as $50 \mathrm{mg} \mathrm{l}^{-1}$

257 inhibited fertilization in Acropora digitifera. Additionally, Humphrey et al. (2008) saw reduced

258 fertilization in A. millepora when exposed to suspended sediments (100 $\mathrm{mg} \mathrm{l}^{-1}$ and $\left.200 \mathrm{mg} \mathrm{l}^{-1}\right)$.

259 Gilmour (1999) exposed Acropora digitifera larvae to suspended sediment (20 mg 1-1 and $50 \mathrm{mg}$

$2601-1)$ and there was significantly greater mortality $(>98 \%)$ in the sediment treated larvae.

261 Ricardo et al. (2015) found that fertilization decreased in the presence of suspended

262 sediment, which was compounded by lowering the concentration of sperm available. When

263 exposed to suspended sediment concentrations of $230 \mathrm{mg} \mathrm{l}^{-1}$ and $700 \mathrm{mg} \mathrm{l}^{-1}$, they determined that

264 2-37 fold more sperm was needed in order to equal fertilization rates seen in sediment-free

265 treatments. In this study we used an optimal sperm concentration for fertilization in M. capitata

266 (Maté et al. 1997) which may have made fertilization more resilient to the sediment treatments.

267 Humanes et al. (2017) performed similar experiments to this study but also looked at the

268 combined effects of sediment, temperature, and nutrients on the early life stages of Acropora

269 tenuis. They found that fertilization was most sensitive to high suspended sediments $\left(100 \mathrm{mg} \mathrm{l}^{-1}\right)$

270 while larval survival and settlement were not affected.

271 In Hawai'i, studies have shown that the coral in Kāne'ohe Bay show some resilience to

272 sediment during gametogenesis and larval survival but not settlement. Padilla-Gamiño et al.

273 (2014) looked at the effect of sediment on gametogenesis in M. capitata and found no difference 
274 in gamete production between sites with high and low sediment regimes. Perez III et al. (2014)

275 exposed larvae of Pocillopora damicornis to substrate covered in varying levels of fine sediment

$276(0.008-0.08 \mathrm{~mm})$. They found that larval survival was not impacted by sediment but a thin layer

$277\left(>0.9 \mathrm{mg} \mathrm{cm}^{-2}\right)$ of fine sediment could completely block settlement of larvae. Ricardo et al.

278 (2017) also found that very thin layers of deposited sediment can block settlement and this was

279 consistent regardless of sediment type (carbonate and siliciclastic) and particle size (fine and 280 coarse silt).

281 Sediment type and composition has been shown to have varied effects on coral

282 fertilization (Ricardo et al. 2018). Sediments with high organic-clay or certain minerals (i.e.,

283 Bentonite) decreased fertilization even at low suspended sediment concentrations. In contrast,

284 terrigenous sediments with low organic matter only decreased fertilization at high suspended

285 sediment levels $\left(>100 \mathrm{mg} \mathrm{l}^{-1}\right)$. In this study we used terrigenous red clay but did not analyze the

286 sediment for its organic or mineral composition. Low organic composition could explain

287 fertilization resilience to suspended sediments seen in this study.

288

289 Effects of low salinity on early life stages

290 Scleractinian corals are known to be stenohaline and osmoconformers. Corals do not

291 have a developed physiological regulatory system thus, osmotic stress on corals may cause

292 damage at the cellular level. A rapid increase in the induction of heat shock proteins may result

293 from changes in salinity (Seveso et al. 2013). Lowered salinity did not have an effect on

294 fertilization but did decrease larval survival and settlement. Kāne'ohe Bay has nine perennial

295 streams that feed directly into it, which could explain why M. capitata appear to have some

296 resilience to low salinity during fertilization. A few other studies have examined how low 
297 salinity affects fertilization, larval survival, and settlement but none have included Hawaiian

298 coral. Humphrey et al. (2008) exposed Acroporid gametes to different salinities (28 to $36 \%$ ) and

299 documented reduced fertilization at $30 \%$ and no fertilization at $28 \%$. Similarly, Hedouin et al.

300 (2015) exposed gametes of two Acroporid species to different levels (26 to $36 \%$ ) of salinity and

301 found that salinities $\leq 28 \%$ ( 26.6 and $27.1 \%$ ) reduced fertilization success in both species.

302 Hedouin et al. (2015) also found that lowered salinity decreased larval survival. The results from

303 the present study are more consistent with those of Chui \& Ang Jr. (2015). They exposed

304 gametes of Platygyra acuta to several different salinities and found that fertilization success was

305 statistically the same from 32 to $28 \%$ with significant decreases at $26 \%$, suggesting that some

306 species of coral may be more tolerant to lowered salinities.

307

308

309

Effects of high temperature on early life stages

Exposing the early life stages of $M$. capitata to elevated temperature for $24 \mathrm{~h}$ following 310 spawning had negative latent effects on larval survivorship but did not directly impact

311 fertilization. Gametes and embryos held at high temperature during this experiment had a lower

312 mean fertilization but it was not different from the percent fertilization of the control. The results

313 from the present study are consistent with studies performed on coral from Okinawa where Negri

314 et al. (2007) found that Favites chinesis had high fertilization success even at $31.8^{\circ} \mathrm{C}(\sim 79$ -

315 91\%). Other studies have shown that elevated temperature negatively affects larval survival and

316 settlement. Bassim \& Sammarco (2003) and Edmunds et al. (2001) found elevated temperature

317 treatments increased mortality in coral larvae. Coral settlement was also found to be negatively

318 affected by elevated temperature (Bassim \& Sammarco 2003; Randall \& Szmant 2009). 
319 Humanes et al. (2017) found that elevated temperature (31 and $\left.32^{\circ} \mathrm{C}\right)$ decreased fertilization,

320 larval development, and settlement in Acropora tenuis.

321 In this study, there was no statistical difference in the percent settlement of $M$. capitata

322 larvae between the control and the treatments. However, the results of the settlement experiment

323 are lacking due to low replication at the settlement stage (Table 2). Following the same cohort of

324 gametes and embryos through fertilization, larval survival, and settlement resulted in important

325 information about the lasting effects of a short-term exposure to stressors. However, this led to

326 an inherent loss of sample size for settlement results.

327

328 Conclusion

Kāne'ohe Bay is a calm, protected lagoon and M. capitata is one of the major reef

330 building coral there. As climate change accelerates, more frequent episodic largescale storms and

331 hurricanes will impact the main Hawaiian Islands (Li et al. 2018). Storms may produce a lens of

332 warm hyposaline water with increased suspended sediments that result in high mortality in the

333 early life stages of $M$. capitata when spawning is synchronous to flooding. Our study showed

334 that these stressors did not affect fertilization, but there were negative latent effects on larval

335 survival. Most notably, gametes and embryos exposed to salinity of $28 \%$ for 24 hours had less

336 than 1\% larval survival while those exposed to sediment decreased larval survival by

337 approximately $55-81 \%$ and increased temperature reduced larval survival by $48 \%$ as compared to 338 the control.

339 This study reveals new, valuable information on how near shore stressors such as runoff

340 and elevated temperature affect the early life stages of a Hawaiian coral. Results that increase the

341 understanding of the impact of local stressors on early life stages can provide managers with 
342 sound science to develop management strategies for the conservation and protection of coral

343 reefs. Managers will be able to use this information in coral reef management programs such as

344 outplanting coral fragments. Outplanting of reef building corals into areas that have lost cover or

345 onto artificial reefs has become a popular method of reef restoration. Growth of adult colonies

346 and asexual reproduction through fission or fragmentation can increase coral cover, but the long-

347 term success of these outplanted populations depends on the genetic diversity and successful

348 recruitment of sexually produced offspring. Understanding how the early life stages of corals are

349 affected by near shore stressors will assist managers with outplanting corals in suitable habitat

350 for adult growth and reproduction as well as recruit new larval corals.

Future studies involving all of the near shore stressors should include varying

352 concentrations of sperm, combinations of stressors, species with different reproductive strategies

353 (brooding vs. spawning), and multiple coral species. It is important to use different

354 concentrations of sperm because an optimal sperm concentration is 1) not realistic for in situ

355 concentrations and 2) could mask deleterious effects of the near shore stressors. Also,

356 availability of sperm has been shown to have a strong influence on successful fertilization in

357 corals (Ricardo et al. 2015). It has been shown that there is inherent variability in quality and

358 sensitivity of coral gametes and their larvae from different nights of spawning and should be

359 taken into consideration when conducting future experiments (Hédouin \& Gates 2013). It is also

360 important to see whether the effects of near shore stressors change when combined. Therefore, a

361 factorial design where near shore stressors are combined to determine if effects are additive,

362 synergistic, or antagonistic (Chui \& Ang Jr. 2015; Humanes et al. 2017). Lastly, it is important to

363 study the effects of near shore stressors on different species of coral and corals with different 
364 reproductive strategies. Other studies have shown that different coral species from the same reef

365 system respond differently to stressors (Hedouin et al. 2015; Negri et al. 2007).

366 It is important for the conservation and protection of coral reefs that effects of near shore

367 stressors on early life stages of corals be studied. The resilience and recovery of coral reefs is

368 highly dependent on successful reproduction and settlement of larval corals.

\section{Acknowledgements}

372 Gin Carter, Julio Camperio Ciani, Alison Dygert, and Reuben Schleiger contributed to field work 373 and gamete collection.

\section{References}

376

377

378

379

380

381

382

383

384

385

386

387

388

389

390

391

392

393

394

395

396

397
Babcock RC, Bull GD, Harrison PL, Heyward AJ, Oliver JK, Wallace CC, and Willis BL. 1986. Synchronous spawnings of 105 scleractinian coral species on the Greate-BarrierReef. Marine Biology 90:379-394.

Bahr K, Jokiel P, and Toonen R. 2015a. The unnatural history of Kāne'ohe Bay: coral reef resilience in the face of centuries of anthropogenic impacts. PeerJ 3:e950 https://doi.org/10.7717/peerj.950.

Bahr KD, Jokiel PL, and Rodgers KS. 2015b. The 2014 coral bleaching and freshwater flood events in Kāne'ohe Bay, Hawai'i. PeerJ 3:e1136; D0I 10.7717/peerj.1136.

Bahr KD, Rodgers KS, and Jokiel PL. 2017. Impact of three bleaching events on the reef resiliency of Kāne'ohe Bay, Hawai'i. Frontiers in Marine Science 4:368. 10.3389/fmars.2017.00398

Banner AH. 1968. A freshwater "kill" on the coral reefs of Hawai'i. Hawai'i Institute of Marine Biological Technology Report 15:1-29.

Bassim K, and Sammarco P. 2003. Effects of temperature and ammonium on larval development and survivorship in a scleractinian coral (Diploria strigosa). Marine Biology 142.

Bellwood DHTP, Folke, C.; Nyström, M. . 2004. Confronting the coral reef crisis. Nature 429:827-833. doi:10.1038/nature02691

Chui A, and Ang Jr. P. 2015. Elevated temperature enhances normal early embryonic development in the coral Platygyra acuta under low salinity conditions. Coral Reefs 34:461-469.

Peer] reviewing PDF | (2019:10:42666:2:0:NEW 22 May 2020) 
398

399

400

401

402

403

404

405

406

407

408

409

410

411

412

413

414

415

416

417

418

419

420

421

422

423

424

425

426

427

428

429

430

431

432

433

434

435

436

437

438

439

440

441

442

443

De Carlo E, Hoover D, Young C, Hoover R, and Mackenzie F. 2007. Impact of storm runoff from tropical watersheds on coastal water quality and productivity. Applied Geochemistry 22:1777-1797. doi:10.1016/j.apgeochem.2007.03.034

Descombes P, Wisz M, Leprieur F, Parravicini V, Heine C, Olsen S, Swingedouw D, Kulbicki M, Mouillet D, and Pellissier L. 2015. Forecasted coral reef decline in marine biodiversity hotspots under climate change. Global Change Biology 21:2479-2487. $10.1111 /$ gcb.12868

Douglas AE. 2003. Coral Bleaching - how and why? Mar Pollut Bull 46:385-392.

Edmunds P, Gates R, and Gleason D. 2001. The biology of larvae from the reef coral Porites asteroides, and their response to temperature disturbances. Marine Biology 139:981-989.

Erftemeijer PLA, Reigl B, Hoeksema BW, and Todd PA. 2012. Environmental impacts of dredging and other sediment disturbances on corals: A review. Mar Pollut Bull 64:1737-1765.

Fabricius K. 2005. Effects of terrestrial runoff on the ecology of corals and coral reefs: review and synthesis. Mar Pollut Bull 50:125-146.

Gilmour J. 1999. Experimental investigation into the effects of suspended sediment on fertilisation, larval survival and settlement in a scleractinian coral. Marine Biology 135:451-462.

Hagedorn M, Carter V, Lager C, Camperio Ciani J, Dygert A, Schleiger R, and Henley E. 2016. Potential bleaching effects on coral reproduction. Reproduction, Fertility and Development 28:1061-1071. 10.1071/RD15526

Hagedorn M, Farrell A, Carter V, Zuchowicz N, Johnston E, Padilla-Gamino J, Gunasekera S, and Paul V. 2015. Effects of toxic compounds in Montipora capitata on exogenous and endogenous zooxanthellae performace and fertilization success. PLoS ONE 10:e0118364. doi:0118310.0111371/journal.pone.0118364.

Hédouin L, and Gates R. 2013. Assessing fertilization success of the coral Montipora capitata under copper exposure: Does the night of spawning matter? Mar Pollut Bull 66:221-224.

Hedouin L, Pilon R, and Puisay A. 2015. Hyposalinity stress compromises the fertilization of gametes more than the survival of coral larvae. Marine Environmental Research 104:1-9.

Hughes T, Rodrigues M, Bellwood D, Ceccarelli D, Hoegh-Guldberg O, McCook L, Moltschaniwskyj N, Prachett M, Steneck R, and Willis B. 2007. Phase shifts, herbivory, and the resilience of coral reefs to climate change. Current Biology 17:360-365.

Hoover D, and Mackenzie F. 2009. Fluvial fluxes of water, suspended particulate matter and nutrients and potential impacts on tropical coastal water biogeochemistry: Oahu, Hawaii. Aquatic Geochemistry 15:547-570.

Humanes A, Ricardo G, Willis B, Fabricius K, and Negri A. 2017. Cumulative effects of suspended sediments, organic nutrients and temperature stress on early life history stages of the coral Acropora tenuis. Scientific Reports. DOI: 10.1038/srep44101

Humphrey C, Weber M, Lott C, Cooper T, and Fabricius K. 2008. Effects of suspended sediments, dissolved inorganic nutrients and salinity on fertilisation and embryo development in the coral Acropora millepora (Ehrenberg, 1834). Coral Reefs 27:837-850.

Peer) reviewing PDF | (2019:10:42666:2:0:NEW 22 May 2020) 
444 Jokiel PL. 1986. Effects of Marine Mining Dredge Spoils on Eggs and Larvae of a 445 Commercially Important Species of Fish, the Mahimahi (Coryphaena hippurus). $446 \quad$ Marine Mining 8:303-315.

447 Jokiel PL, and Brown EK. 2004. Global warming, regional trends and inshore environmental 448

Jokiel PL, Brown EK, Friedlander A, Rodgers KS, and Smith WR. 2004. Hawai'i Coral Reef Assessment and Monitoring Program: Spatial patterns and temporal dynamics in reef coral communities. Pacific Science 58:159-174.

Jokiel PL, Hunter CL, Taguchi S, and Watarai L. 1993. Ecological impact of a fresh water "reef kill" in Kaneohe Bay, Oahu, Hawaii. Coral Reefs 12:177-184.

Jokiel PL, Rodgers KS, Storlazzi CD, Field ME, Lager CV, and Lager D. 2014. Response of reef corals on a fringing reef flat to elevated suspended-sediment concentrations: Moloka'i, Hawai'i. PeerJ 2:e699. 10.7717/peerj.699

Jokiel PLC, S. L. 1977. Effects of temperature on the mortality and growth of Hawaiian reef corals. Marine Biology 43:201-208.

Jones R, Ricardo G, and Negri A. 2015. Effects of sediments on the reproductive cycle of corals. Mar Pollut Bull 100:13-33.

Kolinski SP, and Cox EF. 2003. An Update on Modes and Timing of Gamete and Planula Release in Hawaiian Scleratinian Corals with Implications for Conservation and Management Pacific Science 57:17-27.

Li, N., Yamazaki, Y., Roeber, V., Cheung, K.F., and Chock, G. 2018. Probabilistic mapping of storm-induced coastal inundation for climate change adaption. Coastal Engineering, 133, 126-141. DOI: 10.1016/j.coastaleng.2017.12.013

Maté J, Wilson J, Field S, and Neves E. 1997. Fertilization dynamics and larval development of the scleractinian coral Montipora verrucosa in Hawai'i. In: Cox EF, Krupp DA, Jokiel PH (eds) Reproduction in Reef Corals Results of the 1997 Edwin W Pauley Summer Program in Marine Biology Hawaii Institute of Marine Biology, Kane'ohe:25-37.

McClanahan T, Ateweberhan M, Muhando C, Maina J, and Mohammed M. 2007. Effects of climate and seawater temperature variation on coral bleaching and mortality. Ecological Monographs 77:503-525.

McManus L, Vasconcelos V, Levin S, Thompson D, Kleypas J, Castruccio F, Curchitser E, and Watson J. 2019. Extreme temperature events will drive coral decline in the Coral Triangle. Global Change Biology. 10.1111/gcb.14972

Negri A, Marshall P, and Heyward A. 2007. Differing effects of thermal stress on coral fertilization and early embryogenesis in four Indo Pacific species. Coral Reefs 26:759-763.

Negri A, Webster N, Hill R, and Heyward A. 2001. Metamorphosis of broadcast spawning corals in response to bacteria isolated from crustose algae. Marine Ecology Progress Series 223:121-131.

Ogden J, and Lobel P. 1978. The role of herbivorous fishes and urchins in coral reef communities. Env Biol Fish 3:49-63.

Oliver LML, J.C.; Fisher, W.S. 2011. Relating landscape development intensity to coral reef condition in the watersheds of St. Croix, US Virgin Islands. Marine Ecology Progress Series 427:293-302.

$10.3354 /$ meps09087 
489 Padilla-Gamiño J, Hedouin L, Waller R, Smith D, Truong W, and Gates R. 2014.

490

491

492

493

494

495

496

497

498

499

500

501

502

503

504

505

506

507

508

509

510

511

512

513

514

515

516

517

518

519

520

521

522

523 Sedimentation and the reproductive biology of the Hawaiian reef-building coral Montipora capitata. Coral Reefs 32:137-152.

Perez III K, Rodgers KS, Jokiel PL, Lager CV, and Lager DJ. 2014. Effects of terrigenous sediment on settlement and survival of the reef coral Pocillopora damicornis.

Randall C, and Szmant A. 2009. Elevated temperature reduces survivorship and settlement of the larvae of the Carribean scleractinian coral, Favia fragum (Esper). Coral Reefs 28:537-545.

Ricardo G, Clode P, and Humanes A. 2015. Suspended sediments limit coral sperm availability. Scientific Reports 5:doi: 10.1038/srep18084(12015).

Ricardo G, Jones R, Clode P, Humanes A, Giofre N, and Negri A. 2018. Sediment characteristics influence the fertilisation success of the corals Acropora tenuis and Acropora millepora. Mar Pollut Bull 135:941-953.

Ricardo G, Jones R, Nordborg M, and Negri A. 2017. Settlement patterns of the coral Acropora millepora on sediment-laden surfaces. Science of the Total Environment 609:277-288.

Richmond R. 1993. Present problems and future concerns resulting from anthropogenic disturbance American Zoologist 33:524-536.

Rodgers KS. 2005. Evaluation of nearshore coral reef condition and identification of indicators in the main Hawaiian Islands PhD. University of Hawaii

Rogers CS. 1990. Responses of coral reefs and reef organisms to sedimentation. Marine Ecology Progress Series 62:185-202.

Seveso, D, Montano G, Strona, Orlandi, Galli, Vai. 2013. Exploring the effect of salinity changes on the levels of Hsp60 in the tropical coral Seriatopora caliendrum Marine Environmental Research. vol 90, pp 96-103. https://doi.org/10.1016/j.marenvres.2013.06.002

Spalding M, and Brown B. 2015. Warm-water coral reefs and climate change. Science 350:769-771.

Te FT. 2001. Responses of Hawaiian scleractinian corals to different levels of terrestrial and carbonate sediment. D Phil Thesis, University of Hawai'i at Manoa.

Uchino K. 2004. Long-term ecological impacts of dredging on coral reefs in Kaneohe Bay, Oahu Masters. University of Hawaii Manoa.

Wilkinson CR. 2000. Status of Coral Reefs of the World: 2000. Cape Ferguson, Queensland, and Dampier, Wester Australia: Australian Institute of Marine Science.

PeerJ reviewing PDF | (2019:10:42666:2:0:NEW 22 May 2020) 


\section{Table $\mathbf{1}$ (on next page)}

Summary of normal and extreme water quality for Kāne’ohe Bay, O’ahu

This table summarizes the average/normal values and extreme (i.e., post-storm or bleaching)

for suspended sediment $\left(\mathrm{mg} \mathrm{l} \mathrm{I}^{-1}\right)$, salinity (\%o) and temperature $\left({ }^{\circ} \mathrm{C}\right)$ in Kāne'ohe Bay, $\mathrm{O}^{\prime}$ ahu. 
1

\begin{tabular}{|c|c|c|}
\hline & Normal & $\begin{array}{l}\text { Extreme } \\
\text { (i.e., storm or bleaching } \\
\text { event) }\end{array}$ \\
\hline \multirow[t]{2}{*}{ Sediment } & $\begin{array}{l}13.1 \pm 0.45 \mathrm{mg} \mathrm{l}^{-1} \\
\text { (Uchino 2004) }\end{array}$ & $\begin{array}{l}600-800 \mathrm{mg} \mathrm{l}^{-1} \\
\text { (Hoover \& Mackenzie 2009) }\end{array}$ \\
\hline & $\begin{array}{l}\text { 1-3 NTU } \\
\text { (De Carlo et al. 2007) }\end{array}$ & $\begin{array}{l}8 \text { NTU } \\
\text { (De Carlo et al. 2007) }\end{array}$ \\
\hline Salinity & $\begin{array}{l}34-35 \% \\
\text { (De Carlo et al. 2007) }\end{array}$ & $\begin{array}{l}>20 \% \\
\text { (De Carlo et al. 2007) }\end{array}$ \\
\hline Temperature & $\begin{array}{l}27^{\circ} \mathrm{C}-\text { summer avg } \\
\text { (Bahr et al. 2015) }\end{array}$ & $\begin{array}{l}30-31^{\circ} \mathrm{C} \\
\text { (Bahr et al. 2015) }\end{array}$ \\
\hline
\end{tabular}

4

5

6

7

8

9

10

11

12

13

14

15

16

17

18

19

20

21

22

23

24

25

26

27

28

29

30 


\section{Table 2 (on next page)}

Summary of sample sizes for the treatments

This table lists the sample sizes of the different treatments at the three early life stages:

fertilization, larval survival, and settlement. There was an inherent loss of sample size throughout the experiment. *Due to low sample size, differences in settlement were not analyzed statistically. 
1

\begin{tabular}{lccc}
\hline & Fertilization & Larval survival & Settlement* \\
\hline Control & 33 & 28 & 22 \\
$\begin{array}{l}\text { Medium suspended } \\
\text { sediment }\end{array}$ & 28 & 24 & 5 \\
$\begin{array}{l}\text { High suspended } \\
\text { sediment }\end{array}$ & 30 & 30 & 15 \\
Low salinity & 31 & 29 & 12 \\
\hline High temperature & 29 & 21 & 12 \\
\hline
\end{tabular}

2

3

4 


\section{Table 3 (on next page)}

Summary of conditions for the treatments and control

There were five treatments - medium suspended sediment, high suspended sediment, low salinity, and high temperature - and the control. This table lists the suspended sediment, salinity and temperature values for each treatment and control. 
1

\begin{tabular}{lccc}
\hline & $\begin{array}{c}\text { Suspended sediment } \\
\left(\mathrm{mg} \mathrm{l}^{-1}\right)\end{array}$ & Salinity (\%o) & Temperature $\left({ }^{\circ} \mathbf{C}\right)$ \\
\hline 1. Control & 0 & 34 & 27
\end{tabular}

2. Medium

100

34

27

suspended sediment

3. High suspended 200

34

27 sediment

4. Low salinity

0

28

27

5. High temperature

0

34

31

2

3 


\section{Figure 1}

Diagram of early life stages and exposure timing

Diagram illustrating the $24 \mathrm{~h}$ exposure of stressors to the early stages of $M$. capitata.

Exposure began prior to egg-sperm bundle breakup and lasted through the non-motile round stage. Fertilization success was measured at $8 \mathrm{~h}$ and $24 \mathrm{~h}$. Then at $24 \mathrm{~h}$, the embryos were transferred to clean vials (labeled treatment stressors) but now with filtered seawater with ambient salinity and temperature. These same treatments were assessed for larval survival at $48 \mathrm{~h}$ and were finally placed into petri dishes for settlement. Settlement was counted 14 days after spawning. Figure adapted from Jones et al. 2015.

Egg-sperm bundle
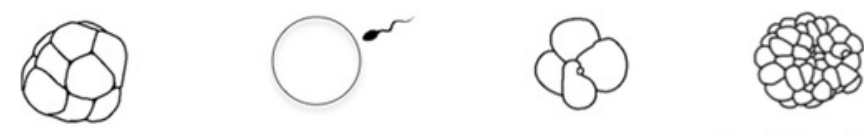

Fertilization

(8 hr)

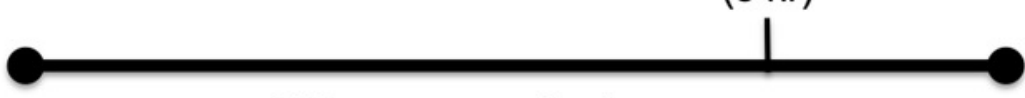

$24 \mathrm{hr}$ exposure to stressors
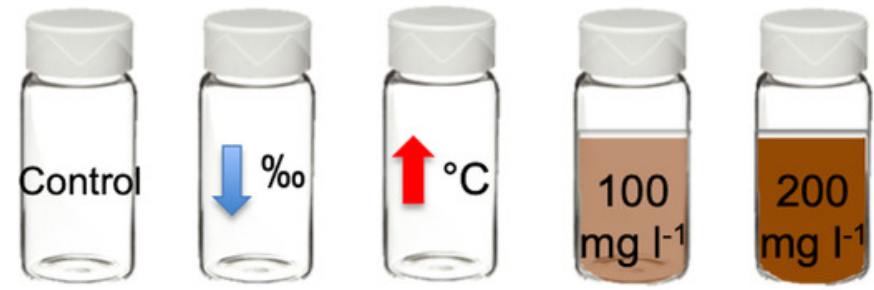

Round stage
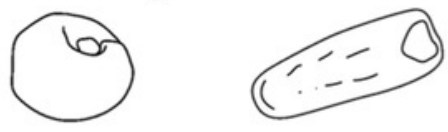

Larval survival

(48 hr)

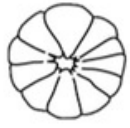

Settlement (14 d)
Latent effects

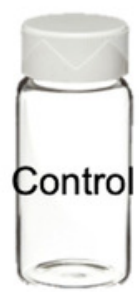


Figure 2

Effects of near shore stressors on early life stages

The early life stages of $M$. capitata were exposed to increased suspended sediment, low salinity, and increased temperature. The percent fertilization, larval survival, and settlement for each treatment and control is graphed.

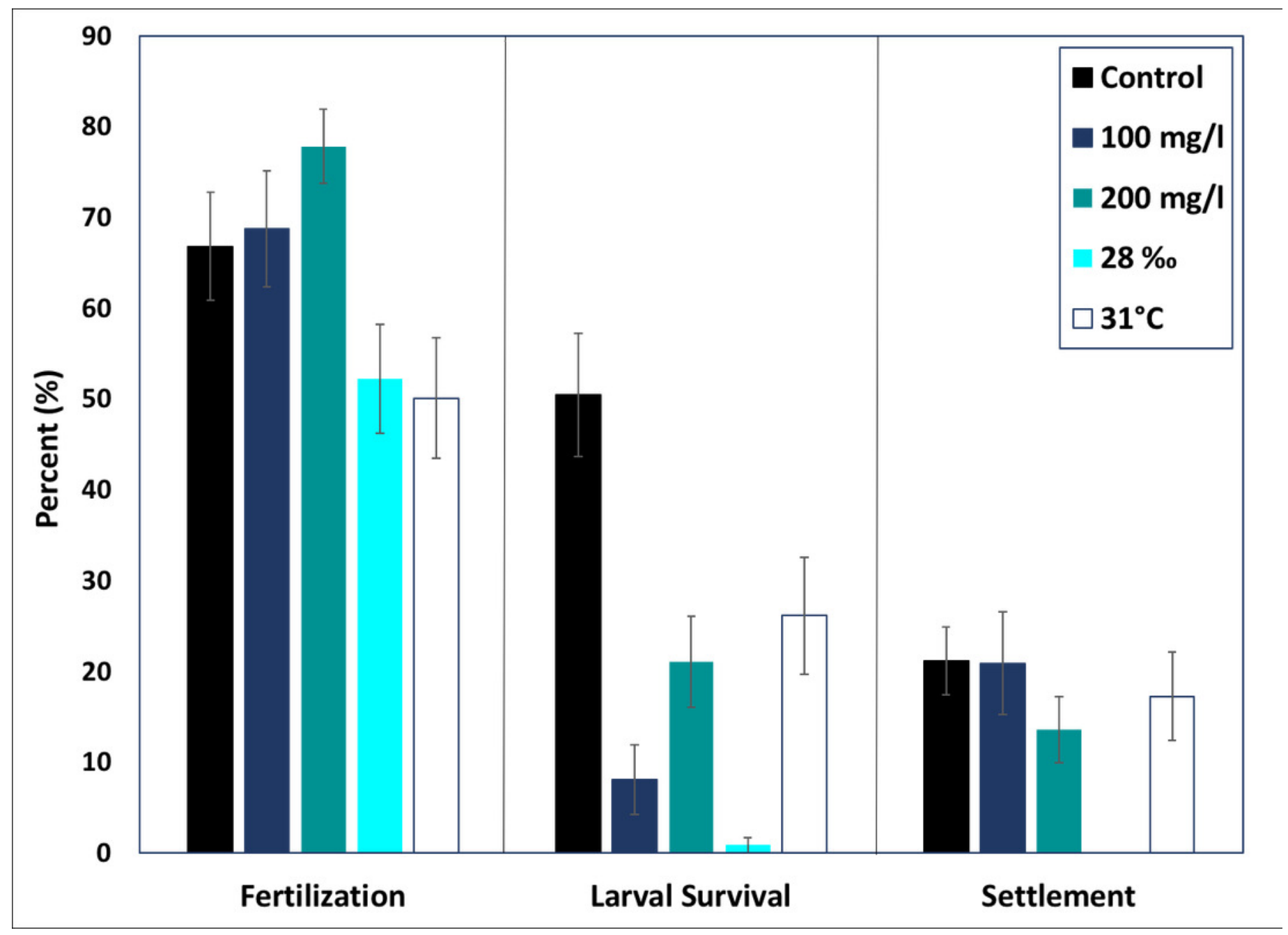

